\title{
NONFIGURATIVE APPROACH: SUSTAINABLE ADAPTIVE REUSE TO RESPOND TO CITY'S EVOLUTION
}

\author{
B Laksitoadi ${ }^{1}$, E C Cattaneo ${ }^{2}$ \\ Received:May $14^{\text {th }}, 2019$ \\ Accepted: September 1 ${ }^{\mathrm{St}}, 2019$
}

\begin{abstract}
This paper describes an approach of adaptive reuse on an abandoned buildings due to the rapid changes of economy and policy in the city. The keyword 'nonfigurative' is used because this approach is focused on creating connections and relationship rather than a physical building. Two other keywords are also used to support it. 'Contextual' means that history, spirit of place (genius loci), and existing set of rules given by the existing building are the key starting point while 'flexible' means that the product of this approach must have the ability to respond to the ever-changing needs of a city. Nowadays, buildings are left obsolete far earlier that its life span initially assumed. This situation often leaves us with ruins in the landscape or even in the middle of our city. In the era of uncertainty where city evolves swiftly due to the rapid changes of economy, policy, and technology, we believe that a nonfigurative approach is a sustainable way to respond to this problem. It will be able to maximize the unexplored potential of an obsolete or even an abandoned building, and equip them with the ability to evolve along with the city.
\end{abstract}

Keywords: adaptive reuse, nonfigurative, contextual, flexible

\section{INTRODUCTION}

Agriculture is a key factor for the development of civilization because it can support a large number of people in one place. This is the reason why early civilization always starts on fertile land and usually on the river banks, such as the Tigris in the Mesopotamia, the Indus Valley in India, the Yellow River in China, Nile riverbanks in Africa, or the Amazon basin in South America.

Agriculture also frees people's time, and with the specialization of labour, they don't need to spend all day working in the field. With this condition, at least some of them can do other things like studying or inventing things and becoming experts on it. This expertise is the factor that eventually builds the civilization and the city.

Along with time and the advancement of technology, city evolves. Cedric Price's three-part diagram, "The City as an Egg" (1982), shows the evolution of the city from a boiled egg (the ancient city that was surrounded by walls) to a fried egg (the industrial city that sprawls because of the invention of steam engine) and finally to the modern city depicted as a scrambled egg that tends not to have a specific city centre because everything is distributed evenly in small granules.

\footnotetext{
${ }^{1}$ Department of Architecture, Faculty of Engineering Universitas Indonesia, Indonesia

${ }^{2}$ Department of Architecture and Urban Studies, Politecnico di Milano, Italy
} 
Unlike the ancient cities, modern city don't have to be established along river banks. With the concentrated collection of infrastructures like highway, railroad, and ports, it can flourish with the constant flow of goods from neighbouring cities or even cities from across the world. A phenomena that was originally coined as megalopolis by (Gottmann, 1961)

This evolution, also influenced by political and financial situation, often leaves ruins in the landscape or even in the middle of the city. One of the most interesting examples is the rapid changes of New York that leaves its railway system unused and effectively abandoned in 1980 (Risselada \& van den Heuvel, 2006). However, its elevated structure was left standing in the middle of the street. With the financial crisis in 2007-2008, city authorities have limited resources to deal with the obsolete infrastructure (Allen, 2002)

Architects are usually good at resourceful strategic thinking. Given this complicated situation, High Line revitalisation project led by James Corner Field Operations turns out to be the most influential, important, and distinctive example of adaptive reuse (Corner, 1999; Corner \& Waldheim, 2006; Marot, 1999; Waldheim, 2010; Wall, 1999). With the collaboration of Diller Scofidio+Renfro, Piet Oudolf, and many other expert specialists, they created a 2.3-kilometer long public park that was built on the abandoned elevated railway. Starting from the competition in 2004, this revitalization project was divided into several phases due to the grand scale of the park. Phase one and two of the park were opened in 2009 and 2011 respectively and the final phase was completed in 2014 (Cairns \& Jacobs, 2017)

By recycling the elevated railway into an urban park, this project gives the citizen the much needed green space and maximizes the hidden potential of the elevated structure. This project has also revitalized its neighbourhoods which was in generally poor condition.

Nowadays, we commonly call this design strategy 'adaptive reuse'. However, this is not a totally new strategy because since the Renaissance period, monuments from ancient times were often transformed for new uses and materials from one building used in the construction of another. Throughout the centuries, various architectural strategies for adaptive reuse have also been developed. It is a phenomenon that is both challenged and propelled by economic, ecologic, cultural, social, and political concerns (Plevoets \& Van Cleempoel, 2013, 2014; Sarkis, Allard, \& Hyde, 2001; Smithson, 1974) (Sarkis H, 2000)

\section{Study Case: Piacenza}

Italy has one of the greatest biodiversity in Europe, not only because of the geomorphological conditions, but also because of the techniques and type of agricultural production in use. One of its regions in the north, Emilia-Romagna, is easily recognizable as a part of the Italian agricultural heritage due to their shape and layout.

Flourished as an agricultural city on the bank of Po River and being one of the cities of "Megalopolis Po" that extends from Turin to Venice, (Theorized by Italian geographers Eugenio Turri (Turri, 2000) in his study La Megalopoli Padana) Piacenza inherits great potentials both from natural resources (water and fertile soil) and infrastructural facilities (highway and railway network).

Precisely because of the strategic geographical location, Piacenza has also been an area of great interest from the military point of view. From the Roman era until this modern time, numerous facilities such as barracks, storage areas, rail track, and logistics centers, have been established throughout the centuries. However, with the rapid economic changes that occurred in Europe in the last couple of years and the change of requirements and priorities in the army (especially NATO), some of the facilities are under-utilized or even abandoned. One of the abandoned facilities is the military compound on the west perimeter of Piacenza (Sheppard, 2013).

This compound is situated in a diverse area surrounded by shops, restaurant, supermarket, hotel, offices, and single landed houses. There are also school and public park not far from it. The compound itself has a huge open space with big trees growing throughout 
the place. However, with the limited access policy and walls surrounding the perimeter, it is impossible for this facility to integrate with its neighborhood.

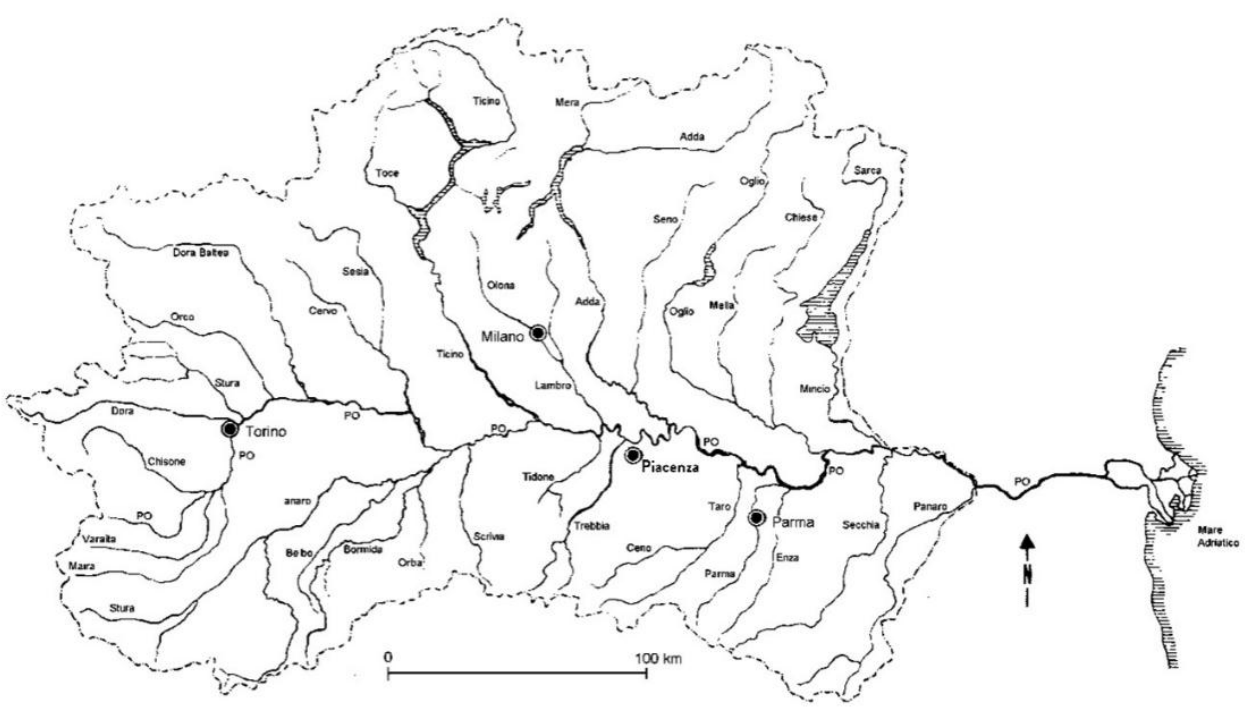

Source: Istituto di Idraulica, Universita di Padova

Figure 1. Network of Po River

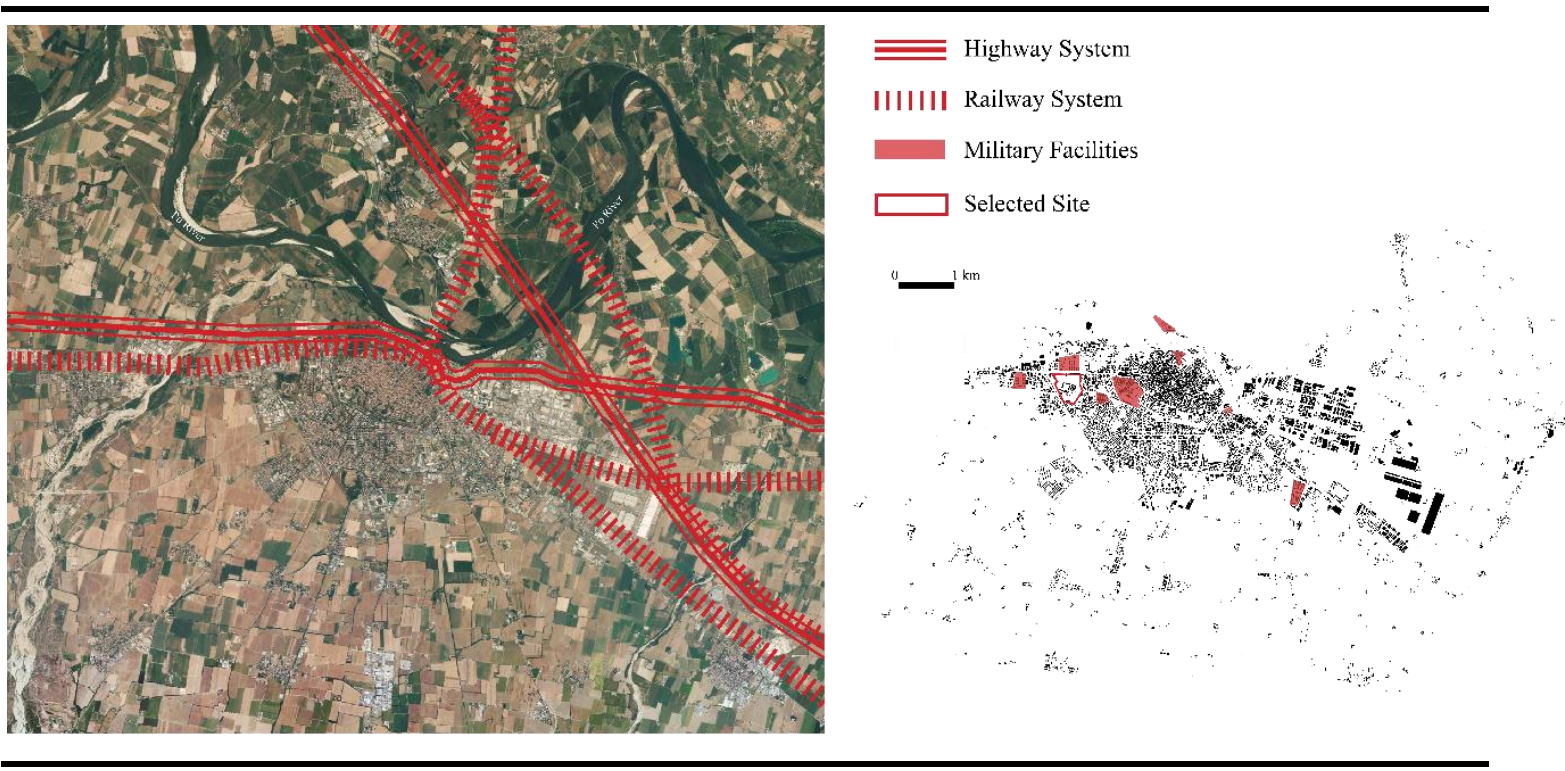

Figure 2. Piacenza

\section{Theoretical Development}

As urban areas sprawl and shrink in Europe (particularly in Italy) and constantly demand clean-up and reprograming, there is also an urge to rethink the landscape with an intelligence of place. Interpreted not so much on Martin Heidegger's and Christian NorbergSchultz's genius loci, but more in Elia Zenghelis's contemporary interpretation of uncovering existing logics of reality and finding a site's capacity by distinguishing the junk from the potentials (Rekittke, Paar, der Sande, \& Foré, 2008) . On the other hand, Italian architect and academic Andrea Branzi refers directly to the contemporary processes of agriculture in his 
call for 'weak urbanization.' The process he promotes is of a relational architecture and urbanism which, like agriculture, is able to quickly adjust to changing needs and seasons (Shannon, 2006)

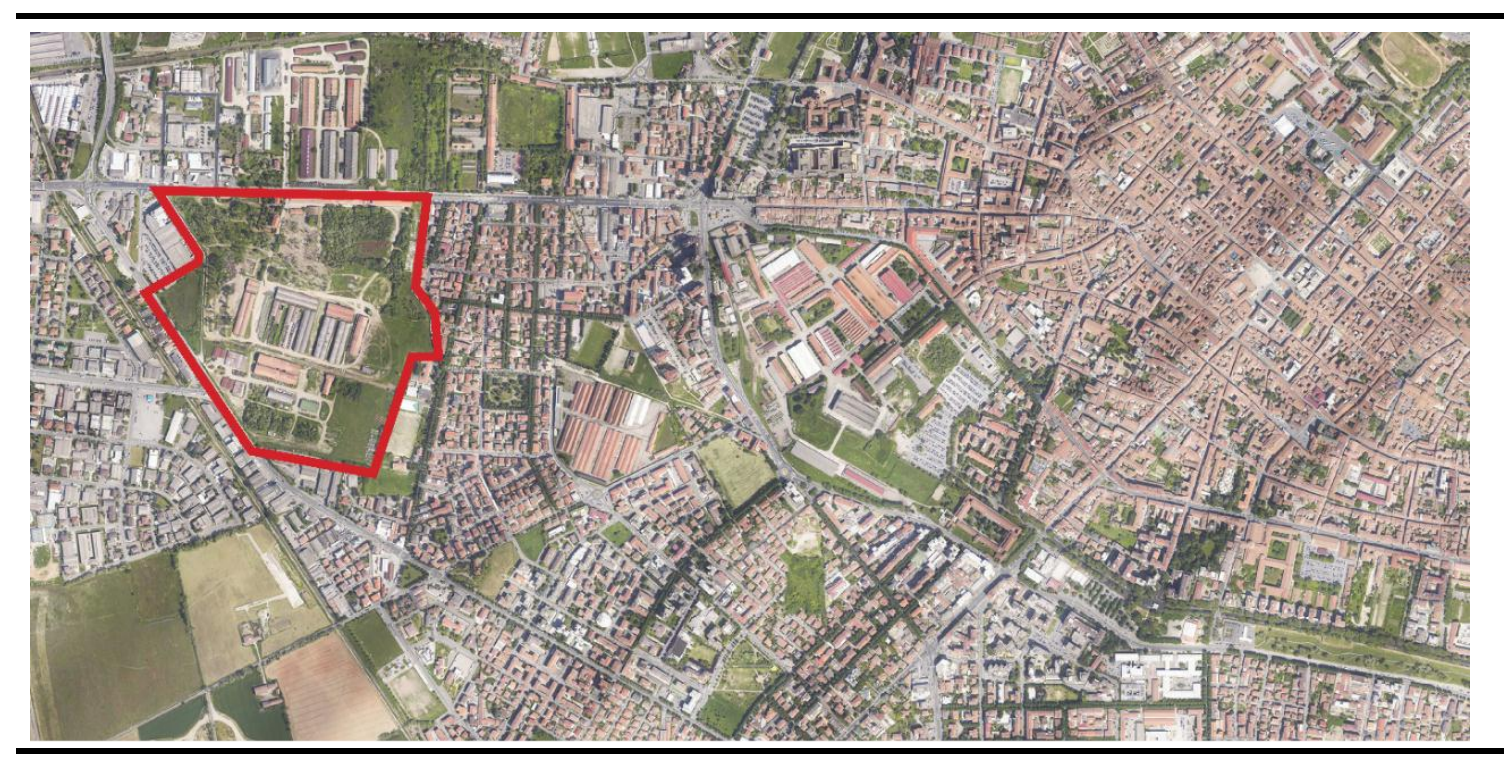

Figure 3. Selected Site

From those two starting points, we also cover other related theories, dated back from the 1970s by Charles Jencks (Jencks, 1977) about post-modern architecture, to the contemporary era from scholars such as Charles Waldheim (Corner \& Waldheim, 2006; Waldheim, 2012) with his Landscape Urbanism. Accompanying these theories, proposals about city and agriculture such as Kisho Kurokawa's 'Agriculture City,' Andrea Branzi's 'Agronica,' and built projects such as 'Free University' by Georges Candilis, Alexis Josic, and Shadrach Woods, are investigated to finally produce three keywords as the strategy to develop our study case (Kisho Kurokawa, 1977; Waldheim, 2010; White \& Przybylski, 2010)

\section{RESULT AND DISCUSSION}

\section{Contextual}

Military world is known to be efficient and effective due to the unpredicted circumstances of military activities especially in conflict zone. In addition, their buildings are also known to be durable and versatile. As an example, Karl Bonatz initially designed a bunker in Berlin in the height of World War II. Later, it was transformed into a prison, a storage facility, a night club, before finally transformed into Sammlung Borros Art Gallery .

Given this versatile set of rules, a series of grids derived from the existing building are established. From the $144 \times 144$-meter grid based on the block plan to the $4 \times 6$-meter interior grid using the structural configuration of the building, these series of grids will become the platform that "allows to be filled in various ways without losing its fundamental identity" and "aims to establish order on a larger scale and to allow flexibility for smaller scale" (Smets, 2002).

With the consideration of heritages and potentials of its regional context, transforming the compound into an agricultural research university will be a good opportunity to develop the compound. Located between the agricultural and sub-urban district, the university can act as a bridge between the production field and its consumers. 


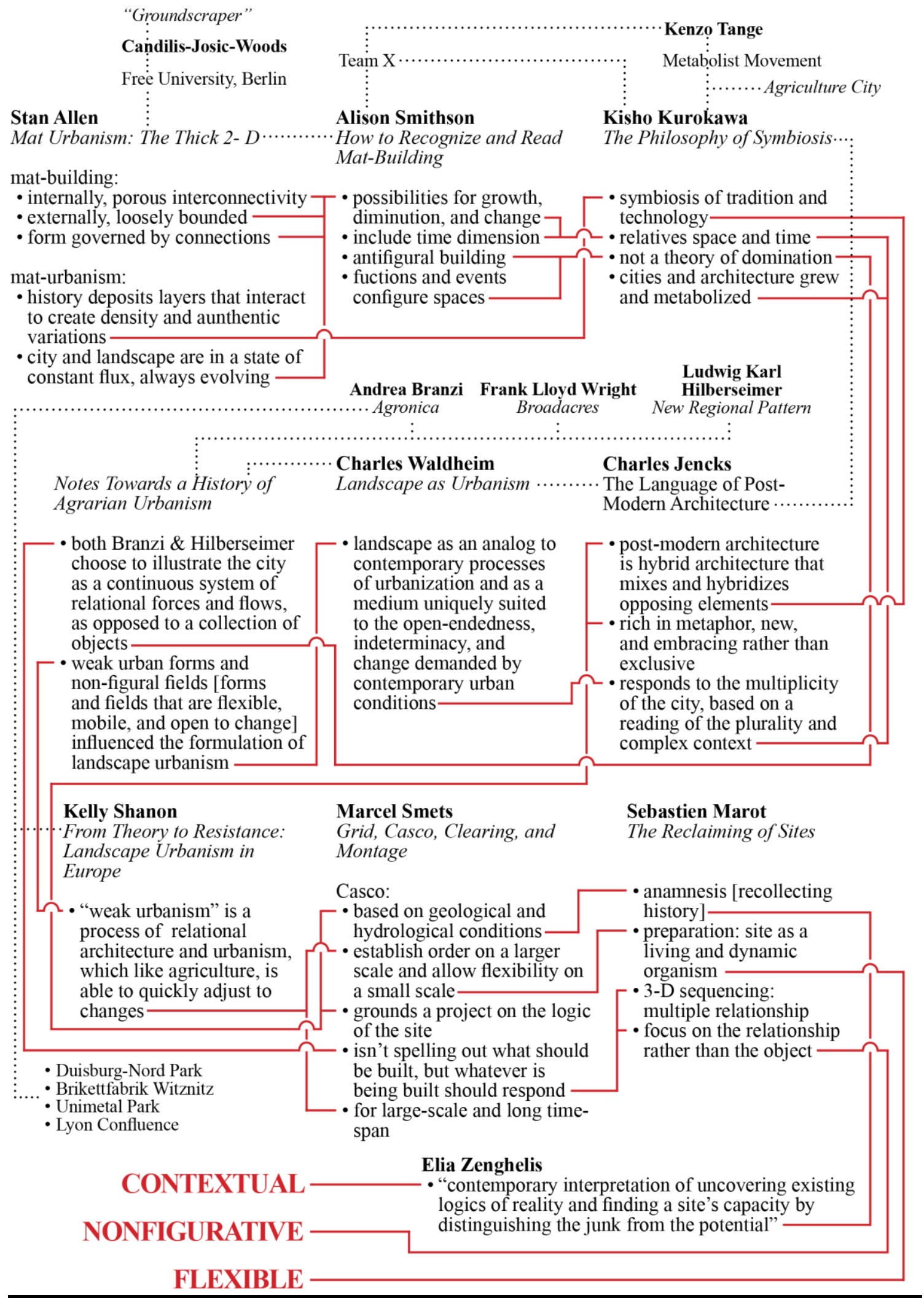

Figure 4. Theoretic Diagram 


\section{Nonfigurative}

The main activities are in the middle of the compound where most of the existing buildings are clustered. It will be surrounded by field laboratories and public parks that also help to create a tranquil environment for studying. To maximize existing infrastructure, some buildings on the perimeter are being reused as guest house, restaurants, and farmers market.

In the main campus, rooms for classes and laboratories are inserted into the building according to the interior grid previously established. By installing glass partition, roofless buildings are converted into a green house. Along with the laboratories and classrooms, other facilities such as library and offices are also accommodated from the variations of the grid.

Ramps are used to create seamless flow from the ground floor to upper floor, while bridges connect one upper floor to another. Unlike elevator that creates a weak relationship between floors, these ramps and bridges will generate a porous interconnectivity throughout the cluster. Just as the premise of 'Free University' in Berlin, this interconnectivity is the tool "to encourage exchange and intellectual regeneration between people in different disciplines, so as to enlarge the field of human knowledge and increase man's control over his collective and individual activities" (Krunic, 2011).

At the end, university is not just about a cluster of buildings with classes but a place for individuals and groups exchanging information, with both tranquil and vibrant spaces to support those activities.

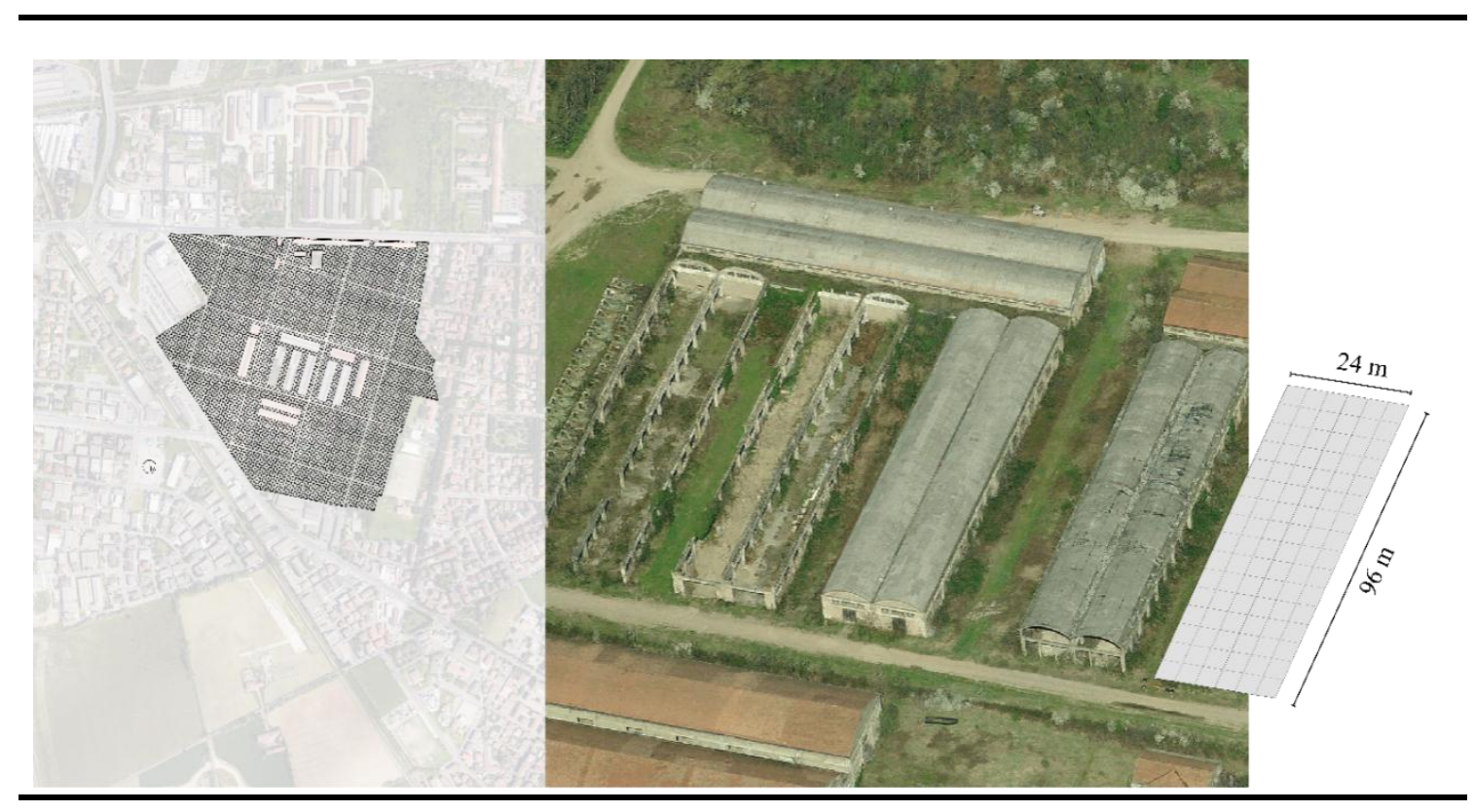

Figure 5. Grid Platform

\section{Flexible}

The term flexible we implied is not as physical changeability since they are rarely realized but as an intermediary space. In his book, Kisho Kurokawa (1994) wrote that intermediary space is a common shared element and a working agreement between two opposing sides. Intermediary space makes a plurality of opposing elements can continue in an ever-changing dynamic relationship that can establish symbiosis and stimulate metamorphosis. 
Educational programs can be established in the public park to educate children about where and how their foods come from. By introducing experimental products, the farmers market can gather public opinions and information. These programs are a form of intermediary space and a communication tool that engage dialogue between university and the public. From these dialogues, the university can quickly respond to the changing demand of the public.

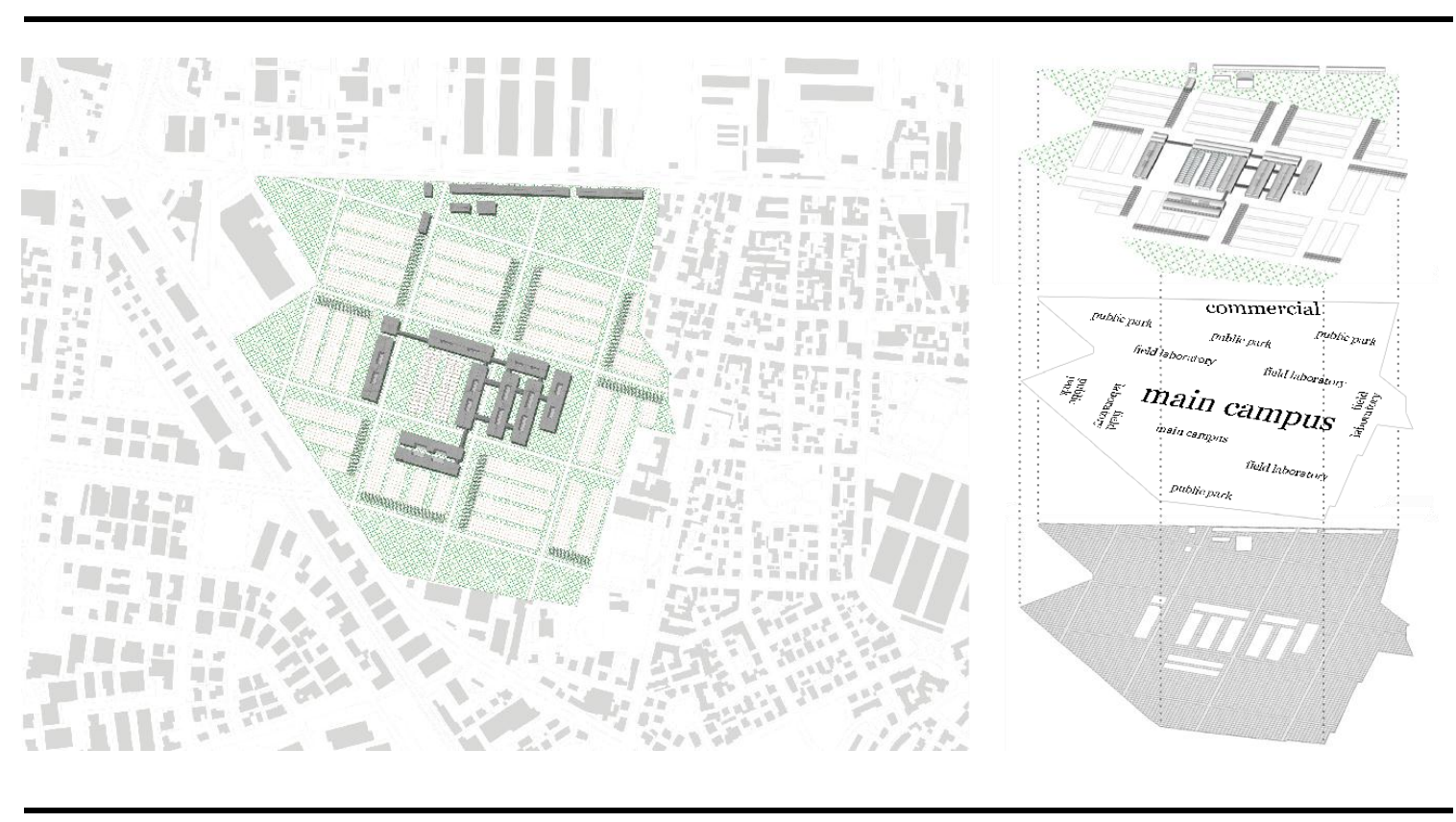

Figure 7. Master Plan

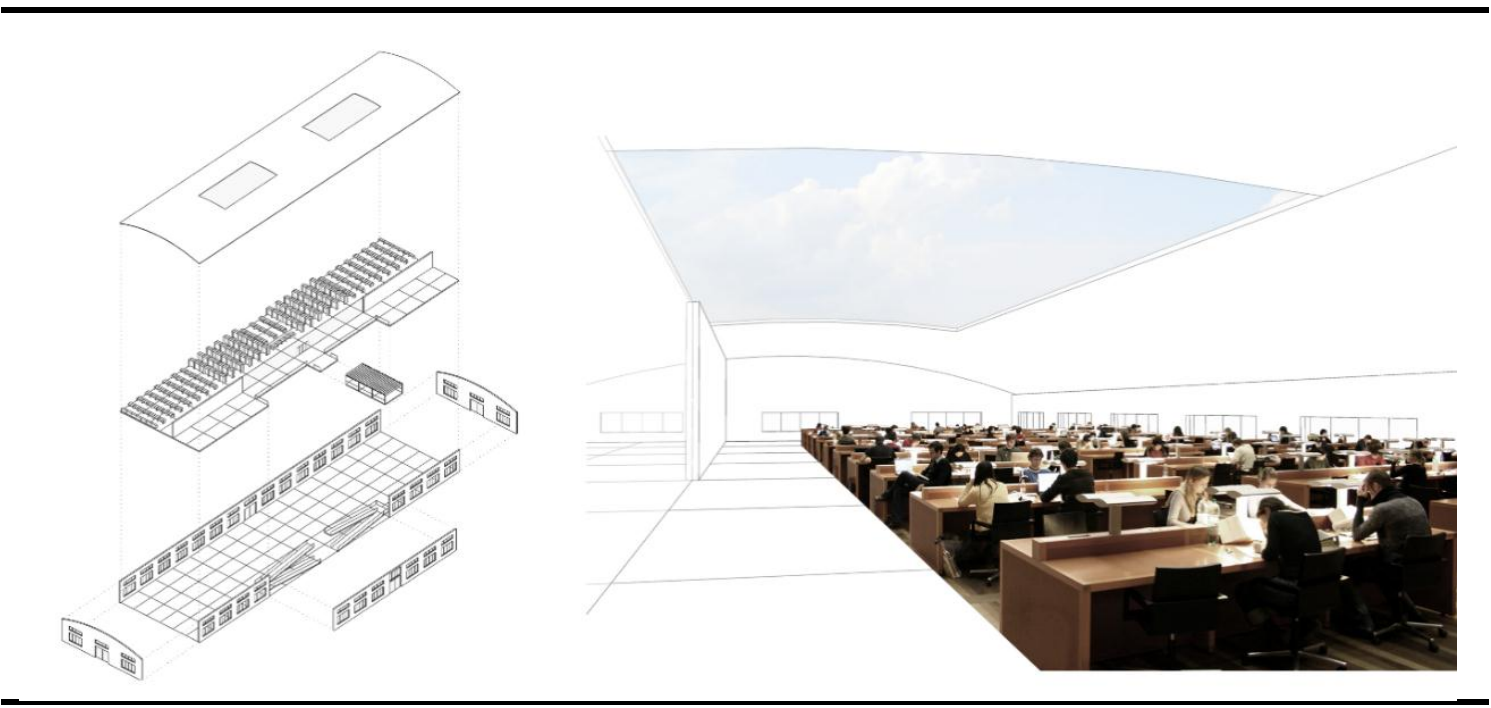

Figure 8. Exploded Isometric and Library Illustration 


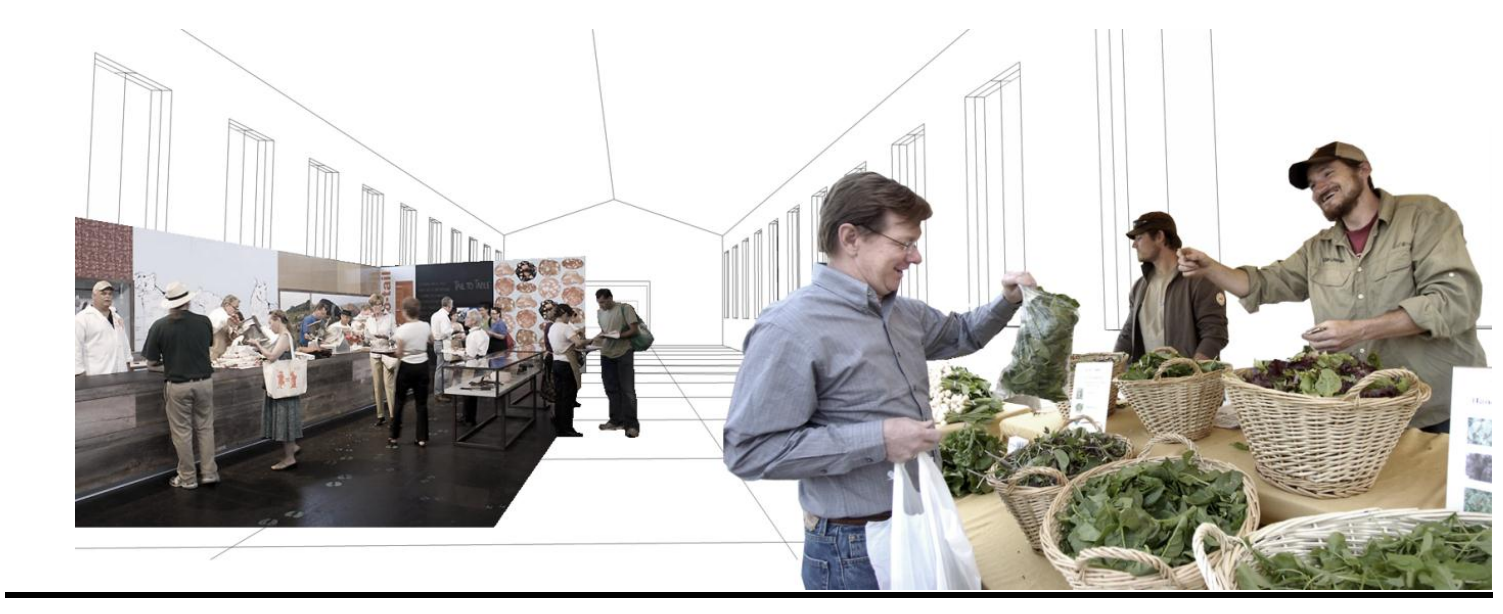

Figure 9. Farmers Market Illustration

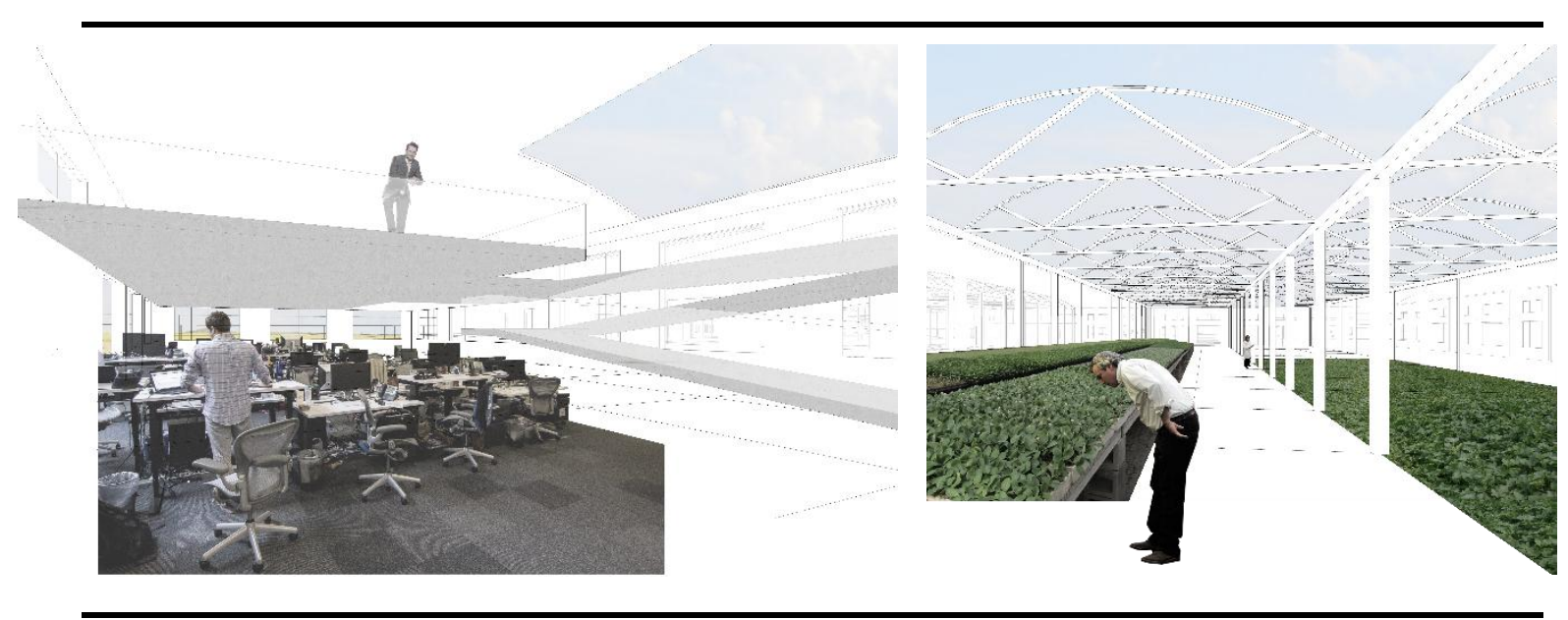

Figure 10. Office and Green House Illustration

\section{CONCLUSION}

Nowadays, buildings are left obsolete far earlier that its initial life span. This situation often leaves us with ruins in the landscape or even in the middle of our city. In the era of uncertainty where city evolves swiftly due to the rapid changes of economy, policy, and technology, a nonfigurative approach is a sustainable way to respond to this problem. We believe this approach will be able to maximize the unexplored potential of an abandoned building and equip them with the ability to evolve along with the city.

\section{REFERENCES}

Allen, S. (2002). Mat urbanism: the thick 2-D (In Sarkis, H., Allard, P, Hyde, T. ed. Case: Le Corbusiers Venice Hospital and the Mat Building Revival). Munich: Prestel Verlag.

Cairns, S., \& Jacobs, J. M. (2017). de la source Buildings must die: a perverse view of architecture. distributeur The MIT Press.

Corner, J. (1999). Recovering landscape: Essays in contemporary landscape theory. Princeton Architectural Press.

Corner, J., \& Waldheim, C. (2006). The Landscape urbanism reader. New York: P-Rinceton Architectural Press.

Gottmann, J. (1961). 1961: Megalopolis: the urbanized northeastern seaboard of the United States. New York: Twentieth Century Fund.

Jencks, C., Jencks, C., Jencks, C., \& Jencks, C. (1977). The language of post-modern architecture.

Krunic, D. (2011). The Groundscraper: Candilis-Josic-Woods' Free University Building, Berlin 1963-1973. UCLA. 
Kurokawa, K. (1977). Metabolism in architecture. Studio Vista London.

Kurokawa, K. (1994). The philosophy of symbiosis. Academy Press.

Marot, S. (1999). The reclaiming of sites. Recovering Landscape: Essays in Contemporary Landscape Architecture, 45-57.

Plevoets, B., \& Van Cleempoel, K. (2013). Adaptive reuse as an emerging discipline: an historic survey. Reinventing Architecture and Interiors: A Socio-Political View on Building Adaptation.

Plevoets, B., \& Van Cleempoel, K. (2014). Aemulatio and the interior approach of adaptive reuse. Interiors, 5(1), 71-88.

Rekittke, J., Paar, P., der Sande, B., \& Foré, P. (2008). 3rd dimension for worldwide landscape architecture. Digital Design in Landscape Architecture, "edited by Erich Buhmann et Al, Heidelberg, Wichmann.

Risselada, M., \& van den Heuvel, D. (2006). Team 10 in search of a utopia of the present: 1953-1981. NAi Publ.

Sarkis, H., Allard, P., \& Hyde, T. (2001). Le Corbusier's Venice Hospital and the mat building revival. Prestel Pub.

Shannon, K. (2006). From theory to resistance: Landscape urbanism in Europe.

Sheppard, L. (2013). From site to territory. Goes Soft: Bracket, 2, 179.

Smets, M. (2002). Grid, casco, clearing and montage. na.

Smithson, A. (1974). How to recognise and read mat--building: mainstream architecture as it has developed towards the mat--building. Architectural Design, 44(9), 573.

Turri, E. (2000). La megalopoli padana. Marsilio.

Waldheim, C. (2010). Notes toward a history of agrarian urbanism. Places Journal.

Waldheim, C. (2012). The landscape urbanism reader. Chronicle books.

Wall, A. (1999). Programming the urban surface. Recovering Landscape: Essays in Contemporary Landscape Architecture, 233-249.

White, M., \& Przybylski, M. (2010). On farming. ACTAR Publishers. 